\title{
Bioremediation of Endosulfan under Solid-State and Submerged Fermentation of Pleurotus ostreatus and its Correlation with Lignolytic Enzyme Activities
}

\author{
Saima Sadiq ${ }^{1 *}$, M. Mahmood-ul-Hassan', Karam Ahad $^{3}$, Muhammad Ishtiaq $^{3}$ \\ ${ }^{1}$ Department of Plant and Environmental Protection, PARC Institute of Advanced Studies in Agriculture \\ affiliated with Quaid-i-Azam University, Islamabad, Pakistan \\ ${ }^{2}$ Land Resources Research Institute, National Agriculture Research Center, Islamabad, Pakistan \\ ${ }^{3}$ Ecotoxicology Research Program, National Agriculture Research Center Islamabad, Pakistan
}

Received: 23 May 2018

Accepted: 7 October 2018

\begin{abstract}
During the past few decades, organochlorine pesticides (OCPs) have emerged as global pollutants. Despite their ban, Endosulfan, one of the most persistent and toxic pesticides of the OCP group, was most commonly used in agriculture and other sectors. Endosulfan bioremediation experiments were conducted using Pleurotus ostreatus. The Endosulfan spiked wheat straw was inoculated with Pleurotus ostreatus and incubated under solid state and submerged fermentation conditions. The enzyme production and activities and degradation of Endosulfan isomers ( $\alpha$ - and $\beta$-isomers) was monitored periodically for 40 days. Degradation rate and half-life (DT50) of both the isomers was calculated using a simple first-order kinetics model. Under both conditions, the addition of Endosulfan showed stimulating effects on MnP and laccase enzyme activities. Activities of both the enzymes at each time interval were higher in solidstate fermentation than submerged fermentation. The degradation of $\alpha$ - isomers was higher under solidstate fermentation than submerged fermentation, while the inverse was true for $\beta$-isomer. The calculated $\mathrm{DT}_{50}$ of $\alpha$ - and $\beta$-Endosulfan under solid-state fermentation was 3.99 and 44 days, respectively, with $73.69 \pm 3.43 \mathrm{mg} \mathrm{kg}^{-1}$ Endosulfan sulfate accumulation. While under submerged fermentation conditions, $\mathrm{DT}_{50}$ of $\alpha$ - and $\beta$-Endosulfan was 10 and 20 days, respectively. The formation of Endosulfan sulfate, under submerged fermentation conditions, was maximum at day $10\left(39.67 \pm 5.73 \mathrm{mgL}^{-1}\right)$ and declined to $8.71 \pm 3.24 \mathrm{mgL}^{-1}$ until the end of incubation. A poor correlation between degradation and activities of both enzymes was observed. Rapid reduction in Endosulfan sulfate under submerged fermentation revealed its ascendancy in degradation over solid-state fermentation.
\end{abstract}

Keywords: bioremediation, submerged fermentation, Solid State Fermentation, endosulfan, Lignolytic enzymes

*e-mail: Saimasadiqqau@yahoo.com 


\section{Introduction}

Endosulfan, a persistent and toxic organochlorine (OC) pesticide, has been used during the past few decades to kill various insects/pests for maximum crop yield. However, due to reported detrimental effects on various components of the ecosystem other than targeted insects/pests $[1,2]$, a ban was imposed on the use of this pesticide. Despite the ban, it is still used as an agricultural pesticide in turf, sugarcane, cotton and many other crops. Its traces can be detected easily in various environmental components like soil, surface water and air due to its high persistence [3]. Pakistan and a few other countries shared the major market of Endosulfan [4]. The point and non-point contamination of the pesticide need appropriate techniques for remediation and management. Bioremediation is a cost-effective and ecofriendly technique compared to other conventional remediation techniques used for Endosulfan [5].

Among the bioremedials, fungi are very well-known for bioremediation of pesticide-contaminated soils as they have substantial potential to degrade organic and inorganic pollutants; white-rot fungi (WRF) are the most effective and prominent among them [6]. Among others, the use of Pleurotus ostreatus for this purpose has been studied widely in the past under different growth conditions [7] like soil, slurry and culture media [8]. Many researchers have connected the bioremediation ability of WRF with the production of lignolytic enzymes [9] that degrade toxic compounds superficially as part of secondary metabolism. Pleurotus spp. has been studied extensively for the production of Laccase (Lac) and Manganese peroxidase (MnP) [10, 11]. Growth conditions of Pleurotus play a key role in the production and expression of lignolytic enzymes [12]. Two growth conditions, i.e., solid-state fermentation (SSF) and enriched submerged fermentation (SMF), are generally used for the growth of fungi. The SSF is a traditional technique in which this fungus is grown on lignocellulosic agricultural byproducts (for example, wheat straws and corn cobs), in the absence/small quantity of free water. Wheat straw, a lignocellulosic agricultural byproduct, is easily available and contains a significant amount of soluble carbohydrates and other inducers of enzyme synthesis. These materials help in the efficient production of lignolytic enzymes [13]. Contrarily, SMF (harvesting of fungus biomass by growing on enriched liquid broth medium) has also received increasing attention and emerged as a promising alternative for efficient production of fungal biomass and enzymes [14]. The bioremediation potential of WRF for different toxic compounds has been tested successfully under both conditions, SSF and SMF, in the past [15].

Broadly, two mechanics of fungal bioremediation are narrated in the literature, i.e., toxic compound degradation due to lignolytic enzymes [16] and adsorption of toxic compounds by mycelial biomass or associated microflora [17]. This study was aimed to: i) assess the Endosulfan bio-remediation potential of P. ostreatus by growing under SSF and SMF conditions and ii) develop a relationship between the degradation of Endosulfan and activities of two extracellular lignolytic enzymes, i.e., laccase and $\mathrm{MnP}$ to determine the role of lignolytic enzymes.

\section{Materials and Methods}

\section{Reagents and Chemicals}

The analytical-grade Endosulfan (99.9\%) used in this study was shipped from sigma Aldrich (St. Louis, Missouri). All the organic solvents, such as acetonitrile, acetone and n-hexane, used for preparing stock/working solution and extraction of samples were of pestanal grade and were obtained from VWR (Radnor, PA). The helium gas used during GC-MS/MS analysis was 99.999\% pure. Growth and maintenance of Pleurotus ostreatus was done using yeast extract, malt extract, peptone, glucose and agar, which were purchased from Merck \& Co. All other chemicals used in enzymes activities analysis, i.e., hydrogen peroxide $\left(\mathrm{H}_{2} \mathrm{O}_{2}\right)$, O-dianisidine (DNS), manganese sulfate, sodium tartrate and ABTS (2,2'-azino-di-[3-ethyl-benzo-thiazolin-sulphonate), were also of analytical grade. For method validation and chromatographic performance evaluation, OCPs Mix AB\#1 (Cat \# 32291 Restek, Bellefonte, PA), internal standard mix (Cat \# 33267 Restek, Bellefonte, PA) and pesticide surrogate mix (Cat \# 32000 Restek, Bellefonte, PA) were used.

\section{Multiplication and Maintenance of $P$. ostreatus}

Yeast-malt-peptone-glucose (YMPG) agar was used for growing pure cultures of $P$. ostreatus (WC814), which were obtained from a mushroom research program at Pennsylvania State University, USA. YMPG media was prepared using a recipe described by Nasim and Co. (2001) [18] using yeast extract, malt extract, peptone, agar and glucose that were added to deionized double-distilled water ( $\mathrm{pH}$ 5.5). After cooling, the media was inoculated with fungal cultures and grown fungal was preserved at $4^{\circ} \mathrm{C}$ for further use during the study.

\section{Bioremediation Microcosms}

\section{Solid-State Fermentation}

Air-dried and ground wheat straws using Ball Mill (Hills Technologies, LLC) were placed in Pyrex flasks and moistened with water to $\approx 77 \%$ in order to promote the activities of $\mathrm{MnP}$ and laccase [15, 19]. The flasks were plugged with a cotton swab to avoid anaerobic conditions and autoclaved at $121^{\circ} \mathrm{C}$ and $15 \mathrm{psi}$ for $30 \mathrm{~min}$. On cooling, straws were inoculated with cultures of the 
Table 1. Summary of quant ion of used internal standard (I.S) and selected organochlorine pesticides $(n=5)$.

\begin{tabular}{|c|c|c|c|}
\hline Compound & $\begin{array}{c}\text { Quant } \\
\text { Ion }\end{array}$ & $\begin{array}{c}\text { Quant } \\
\text { Ion }\end{array}$ & $\begin{array}{c}\text { Quant } \\
\text { Ion }\end{array}$ \\
\hline TMX(I.S)* & 244 & 246 & 242 \\
\hline PCB 18(I.S) & 256 & 260 & 258 \\
\hline PCB 28(I.S) & 256 & 260 & 258 \\
\hline Triphenylmethane(I.S) & 165 & 167 & 166 \\
\hline Endosulfan I & 195 & 197 & 193 \\
\hline $\begin{array}{c}\text { Tris-(1,3-dichloroisopropyl) } \\
\text { phosphate(I.S) }\end{array}$ & 325 & 327 & 326 \\
\hline Endosulfan II & 195 & 197 & 193 \\
\hline Endosulfan sulfate & 387 & 389 & 385 \\
\hline DecaPCB & 498 & 500 & 496 \\
\hline
\end{tabular}

*Internal Standard

P. ostreatus and subsequently spiked with Endosulfan (a) $55 \mathrm{mg} \mathrm{kg}^{-1}$. There were two Controls: i) without fungus but spiked with Endosulfan and ii) with the fungus but not spiked with Endosulfan. Control 2 was used to calculate the effect of Endosulfan on enzymatic activities. Degradation of Endosulfan was monitored by sampling flasks on days 4, 10, 16, 22, 28, 34 and 40. The sampled mixtures were analyzed for Endosulfan immediately.

\section{Enriched Submerged Fermentation (SMF)}

SMF cultures were prepared by pouring YMPG broth medium into Erlenmeyer flasks (rubber-stoppered) and then inoculating with mycelial plugs. Subsequently, the SMF liquid cultures were spiked with a mixture of Endosulfan isomers ( $\alpha$ and $\beta$ 1:1)@ $55 \mathrm{mg} \mathrm{L}^{-1}$. After inoculating the flasks, $100 \%$ oxygen was flushed on a daily basis in order to evade any anaerobic consequence. The spiked SMF cultures were grown at $22^{\circ} \mathrm{C}$ by agitating@125 rpm using an incubator shaker under dark conditions. In addition to the above treatment, two controls were processed in similarly. Control -1 : only YMPG broth medium was spiked with the same rate of pesticides (without mycelial) and Control - 2: mycelial culture of $P$. ostreatus without Endosulfan spiking. Contents of all the flasks were sampled at day 4, 10, 16, $22,28,34$ and 40 days of incubation. The control was used to assess the effect of produced lignolytic enzymes on pesticide reduction and their activities.

\section{Extraction and Analysis}

The QuEChERS (quick, easy, cheap, effective, rugged and safe) method [20] was used for extraction of Endosulfan. After harvesting, samples were placed in a centrifuge tube (Restek, Bellefonte, PA) and mixed with an un-buffered Restek salts kit (containing anhydrous magnesium sulfate and sodium chloride). Then acetonitrile was added as extraction solvents with some water for better phase separation. Six components of internal standard (ISTD) mix and the suspensions were shaken vigorously. The acetonitrile upper layer was removed and analyzed using GC-MS/MS for monitoring the reduction of Endosulfan under both fermentation conditions.

For GC-MS/MS analysis, $60 \mathrm{~m} \times 0.18 \mathrm{~mm} \times$ $0.10 \mu \mathrm{m}$ Rtx Dioxin-2 (Restek, Bellefonte, PA) column was used. Helium was used as carrier gas and the GC was operated with a 10:1 split ratio at a flow rate of

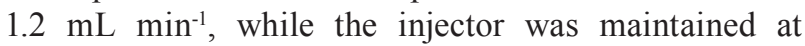
$290^{\circ} \mathrm{C}$. Samples were injected at a final concentration of $1.0 \mu \mathrm{L}$ using an auto sampler. The GC oven temperature program was as follows: initial oven temperature was $100^{\circ} \mathrm{C}$ and hold for $1.0 \mathrm{~min}$. Then the temperature was ramped @ $10^{\circ} \mathrm{C}$ min- 1 to $300^{\circ} \mathrm{C}$ and hold for $7.0 \mathrm{~min}$. The instrument was simultaneously operated in SIM (selected ion monitoring) mode and full-scan mode with electron ionization energy of $70 \mathrm{eV}$ and source temperature of $300^{\circ} \mathrm{C}$. SIM masses used for quantification of Endosulfan and internal standards are given in Table 1.

Quality control (QC) and quality assurance (QA) procedures were followed in order to determine and maintain the quality of analytical data [21]. For calibration, matrix-matched blank extracts $(1 \mathrm{~mL})$ were fortified with $400 \mu \mathrm{l}$ of ISTD solution $\left(20 \mathrm{ng} \mu \mathrm{L}^{-1}\right)$ and with OCP mix in order to get $10 \mu \mathrm{kg}^{-1}$ and $15 \mu \mathrm{kg}^{-1}$ of final concentrations. Accuracy of the method was monitored in terms of recovery (\%) of Endosulfan (Table 2). The results showed that mean recoveries of analytes were between $70-100 \%$, with RSD values at or below $20 \%$ for all analytes [21]. The sensitivity of instruments was measured by calculating the limit of quantitation (LoQ) and limit of detection (LoD) (Table 3).

\section{Lignolytic Enzyme Assays}

At each time series, enzymes under both the conditions were extracted and activities were measured using already-tested protocols [22]. Enzyme extraction

Table 2. Chromatographic performance of GC triple quadrupole mass spectrometer $(n=5)$.

\begin{tabular}{|c|c|c|c|c|c|}
\hline Compounds & $\mathrm{R}_{\mathrm{t}}$ (Minutes) & $\mathrm{r}^{2}$ & Linearity Range & $\operatorname{LoD}\left(\mu \mathrm{g} \mathrm{kg}{ }^{-1}\right)$ & $\operatorname{LoQ}\left(\mu \mathrm{g} \mathrm{kg}{ }^{-1}\right)$ \\
\hline$\alpha$-Endosulfan & 19.52 & 0.999 & $10 \mathrm{pg}-10 \mathrm{ng}$ & 0.001 & 0.01 \\
\hline$\beta$-Endosulfan & 20.96 & 0.998 & $10 \mathrm{pg}-10 \mathrm{ng}$ & 0.001 & 0.01 \\
\hline
\end{tabular}


Table 3. Recovery data of Endosulfan using the proposed procedure under solid-state. fermentation and enriched submerged fermentation $(n=5)$.

\begin{tabular}{|c|c|c|c|c|}
\hline \multirow{2}{*}{ Compounds } & \multicolumn{2}{|c|}{ SSF } & \multicolumn{2}{c|}{ SMF } \\
\cline { 2 - 5 } & Recovery(\%) & RSD (\%)* & Recovery(\%) & 3.46 \\
\hline$\alpha$-Endosulfan & 83.33 & 5.41 & 88.33 & 1.16 \\
\hline$\beta$-Endosulfan & 84.33 & 1.81 & 86 & RS $^{*}$ \\
\hline
\end{tabular}

*Peak Area

was carried out by adding sodium citrate buffer (50 $\mathrm{mM}, \mathrm{pH} 5.3$ ) to the sample. The suspension was mechanically shaken for 30 minutes at $4^{\circ} \mathrm{C}$ on an incubator shaker and squeezed manually using Mira cloth (quick filtration material). Extract was centrifuged twice at $4^{\circ} \mathrm{C}$ (first for 25 minutes at $30,000 \times \mathrm{g}$ and then for 15 minutes at $10,000 \mathrm{x}$ g) using the method described by [23] with slight modifications. Lignolytic enzyme activities were measured in supernatant using a Spectra Max 250 Microplate Reader at different wavelengths. MnP activities were determined by oxidizing o-dianisidine (DNS) and read at $460 \mathrm{~nm}$ (molar extinction coefficient $=29,400 \mathrm{M}^{-1} \mathrm{~cm}^{-1}$ ) for 5 minutes using reaction mixture. Laccase was also measured using ABTS (2,2'-azino-di-[3-ethyl-benzo-thiazolin-sulphonate) as a substrate. For this purpose, ABTS, tartaric $\operatorname{acid}(\mathrm{L}+)$, water and enzyme extract were measured for calorimetric changes at a wavelength of $436 \mathrm{~nm}$ for 5 minutes [22]. Enzyme activities were calculated by the following equation:

$$
\frac{\Delta C}{t}=\frac{\Delta A}{\varepsilon \Delta t . L}
$$

...where $\mathrm{C}$ is the concentration of enzymes, $\mathrm{A}$ is the absorbance, $\varepsilon$ extinction coefficient $\left(\mathrm{Mm}^{-1} \mathrm{~cm}^{-1}\right)$ and $\mathrm{L}$ is path length equal to 0.49 . Activity was expressed in $\mathrm{U} \mathrm{L}^{-1}$, where $1 \mathrm{U}=1 \mu \mathrm{M} \min ^{-1}$.

\section{Kinetic Studies}

Simple first-order kinetics (SFO) fit the observed degradation data with time well. The parameters were calculated using computer program $\mathrm{R}$ (version 3.0.3) with active kin fit software. A degradation $\mathrm{DT}_{50}$ (HalfLife) was calculated by Equation 3 used in line with FOCUS guidelines for each set of laboratory conditions to which samples were exposed [24]. The following linear equation was used [25]:

$$
\ln (C)=a+K_{1} t
$$

...where $\operatorname{Ln}(\mathrm{C})$ is natural logarithm of concentration, $t$ is time given to the compound for degradation, $K_{1}$ is the first-order rate constant (slop) and a is the empirical constant equal to intercept.
$\mathrm{DT}_{50}$ ) was calculated by the following equation

$$
D T_{50}=t_{1 / 2}=\frac{0.693}{k 1}
$$

...where 0.693 is the constant.

\section{Statistical Analysis}

Pearson Correlation between the enzymatic activity and percentage relative reduction of Endosulfan was obtained using statistix (8.1) software.

\section{Results and Discussion}

The purpose of this work was to assess the role of $P$. ostreatus in the degradation of Endosulfan under two growth conditions, i.e., SSF and SMF. The fermentation of this fungus under conditions affect the formation of lignolytic enzyme, e.g., Laccase and MnP [26]. It was considered that these enzymes play a role in bioremediation of different types of pollutants [27]. Therefore, bioremediation of Endosulfan under two fermentation conditions and activities of Laccase and $\mathrm{MnP}$ were monitored simultaneously, and data was recoded periodically during the 40 -day incubation.

\section{Bioremediation under Solid State Fermentation}

Initially, when biomass production of Pleurotus ostraetus in wheat-straw-mediums was very low, about half of the applied $\alpha$-Endosulfan (29 $\mathrm{mg} \mathrm{kg}^{-1}$ ) from the mixture was recovered. This showed that $47 \%$ reduction in applied $\alpha$-Endosulfan occurred in the first 4 days. However, in its associated control, most of this isomer (45 mg kg-1 out of $55 \mathrm{mg} / \mathrm{kg}^{-1}$ ) was recovered on the $4^{\text {th }}$ day. This showed that out of $47 \%$ reduction during the first 4 days, 30\% degradation was most probably due to the inoculated fungus and the remaining $18 \%$ was due to other factors. Significantly less $\mathrm{DT}_{50}$ (3.99 days) of $\alpha$-Endosulfan than control (60.55 days) under SSF conditions indicated the important role of fungal biomass in reducing the amount of $\alpha$-Endosulfan. The recovery of $8 \mathrm{mg} \mathrm{kg}^{-1}$ of this isomer in day 10 indicated that $85 \%$ of the applied isomer was reduced (Fig. 1). The remaining 15\% of this 
isomer was degraded in the next 6 days of incubation. Since $\alpha$-Endosulfan is more bio accumulative and about three times more toxic than $\beta$-Endosulfan [28], complete disappearance before 16 days showed that SSF of $P$. ostreatus is the best method to degrade $\alpha$-Endosulfan. Under control conditions, more than half (32 $\left.\mathrm{mgkg}^{-1}\right)$ was recovered even after the incubation period. The complete disappearance of $\alpha$ - isomer, during the first 16 days by fungus inoculation, was in agreement with the earlier findings, where complete mineralization of Endosulfan was observed after 12 days of incubation with fungal (Aspergillus niger) innoculation [29]. A possible mechanism of the Endosulfan removal could be adsorption by mycelial biomasses of $P$. ostreatus [7].

Under fungal inoculated conditions, the estimated $\mathrm{DT}_{50}$ of $\beta$ - isomer of Endosulfan was 44.12 days, while under associate control it was 341.35 days (Fig. 1). Significantly higher applied $\beta$-Endosulfan was recovered $\left(47 \mathrm{mgkg}^{-1}\right)$ on day 4 and at the end of incubation (31.4 $\left.\mathrm{mgkg}^{-1}\right)$ than that of $\alpha$-Endosulfan. The results showed that after day 16, the disappearance rate of this isomer declined and complete mineralization was not achieved even after the termination of the incubation experiment. In associate control, insignificant degradation of $\beta$-isomer was observed till day 10 (Fig. 1). The decline in rate of $\beta$-isomer mineralization was observed soon after day 16 , when Endosulfan sulfate started to appear in the system. On day 4, $45.7 \mathrm{mg} \mathrm{kg}^{-1}$ of Endosulfan sulfate was observed and was increased to $66.7 \mathrm{mg} \mathrm{kg}^{-1}$ at day 10 . The formation of Endosulfan sulfate was continued till the termination of the experiment $\left(73.7 \mathrm{mgkg}^{-1}\right)$. Surprisingly, no Endosulfan sulfate formation was detected in control. The results were analogous to the fact that the microbial activity and certain fugal enzymes favor oxidative pathways during bioremediation of Endosulfan in soil, resulting in the formation of Endosulfan sulfate [30]. A decline in reduction of both the isomers of Endosulfan with time can be attributed to the accumulation of Endosulfan sulfate, which is considered more toxic and persistent

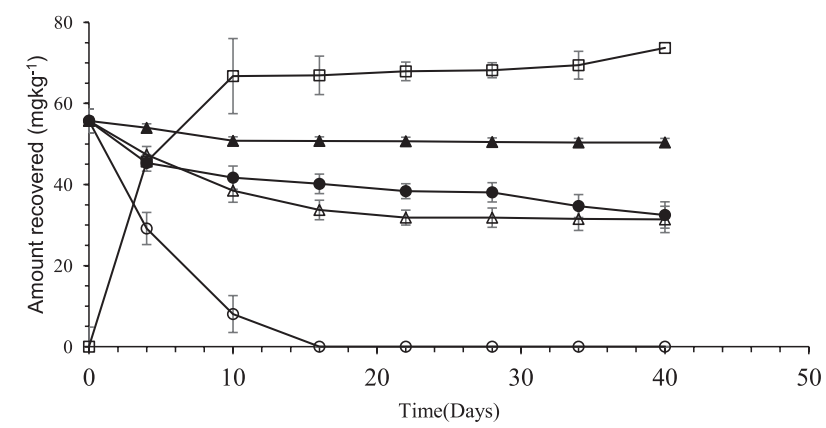

Fig. 1. Recoveries of $\alpha$ and $\beta$ isomers of Endosulfan and the formation of Endosulfan sulfate $\left(\mathrm{mgkg}^{-1}\right)$ under solid-state fermentation ( $\mathrm{n}=3$ ), where $\alpha$-Endosulfan (०), $\alpha$-Endosulfan $($ Control) $(\bullet), \beta$-Endosulfan $(\Delta), \beta$-Endosulfan (Control) $(\mathbf{\Delta})$ and Endosulfan sulfate ( $\square$ )isomer. than its parent compound. Hence, its accumulation during the bioremediation process is a serious concern [31]. However, no other metabolites were detected during the samples analysis, even at a very high injector temperature $\left(290^{\circ} \mathrm{C}\right)$. The formation of Endosulfan sulfate as a major metabolite using WRF, and the corresponding reduction of the parent compound is in line with earlier studies [31]. This formation showed that oxidation was the main cause of degradation of Endosulfan because other hydrolytic metabolic products do not appear during remediation [32]. In this type of study, interconversion of isomers or conversion to metabolites could be another possible phenomenon.

\section{Bioremediation under Submerged Fermentation}

Under SMF conditions, complete degradation/ mineralization of $\alpha$-Endosulfan took 34 days as compared to SSF, where it took only 16 days (Fig. 2). An entirely different trend in reduction and metabolite formation under SMF conditions was observed than that of SSF. Total $\alpha$-Endosulfan recovered, under associated control, was $40.36 \mathrm{mg} \mathrm{L}^{-1}$ (equivalent to $73 \%$ applied dose), and only $15.64 \mathrm{mg} \mathrm{L}^{-1}$ (equivalent to $27 \%$ applied dose) was degraded during the experimental period. On the other hand, total reduction of $\beta$-Endosulfan in associated control under SMF conditions was higher $(87.89 \%)$ than that under SSF (42\%) conditions (Fig. 2). Under SMF conditions, $\mathrm{DT}_{50}$ of $\alpha$-Endosulfan was 9.52 days in fungal inoculated treatment and in associated control, and the $\mathrm{DT}_{50}$ was 106.52 days (Table 4). About 2 times higher $\mathrm{DT}_{50}$ (20.08 days) of $\beta$-Endosulfan was observed than $\alpha$-Endosulfan under the same fermentation conditions, while DT50 of $\beta$-Endosulfan in its associated control was 70 days. Other kinetic perimeters are given in Table 4. Results revealed that that SMF conditions were a good way for lowering the persistence of $\beta$-isomer of Endosulfan. Endosulfan sulfate was detected at day 10 of incubation (39.67 $\left.\mathrm{mg} \mathrm{L}^{-1}\right)$ in this case. However, after that it started declining and within 40 days, only $8.71 \mathrm{mg} \mathrm{L}^{-1}$ of this

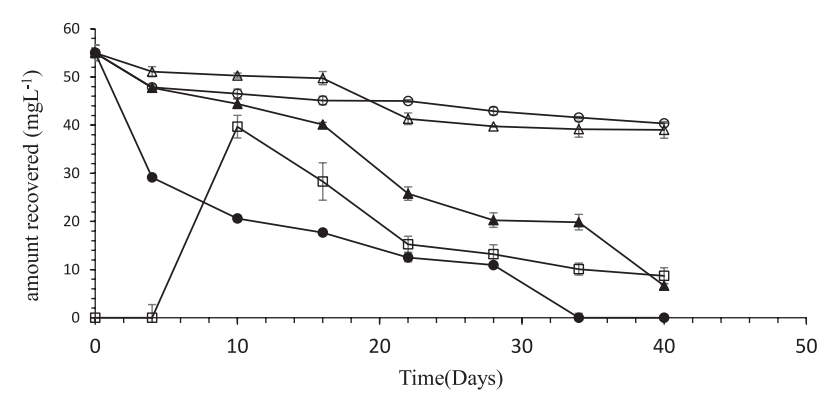

Fig. 2. Recoveries of $\alpha$ and $\beta$ isomers of Endosulfan and the formation of Endosulfan sulfate $\left(\mathrm{mg} \mathrm{kg}^{-1}\right)$ under submerged fermentation $(\mathrm{n}=3)$, where $\alpha$-Endosulfan Control (o), $\alpha$-Endosulfan $(\bullet), \beta$-Endosulfan Control $(\Delta), \beta$-Endosulfan $(\boldsymbol{\Delta})$ and Endosulfan sulfate ( $\square$ ). 
Table 4. Kinetic performance perimeter calculated by single simple first-order equation under SSF and SMF of Pleurotus against Endosulfan.

\begin{tabular}{|c|c|c|c|c|c|c|c|c|}
\hline \multicolumn{9}{|c|}{ Kinetic Perimeters Under Solid State Fermentation and enriched submerged fermentation } \\
\hline \multirow{2}{*}{ Compounds } & \multicolumn{2}{|c|}{$\mathrm{DT}_{50}$} & \multicolumn{2}{|c|}{$\mathrm{DT}_{90}$} & \multicolumn{2}{|c|}{$\mathrm{r}^{2}$} & \multicolumn{2}{|c|}{$\mathrm{k}$} \\
\hline & SSF & SMF & SSF & SMF & SSF & SMF & SSF & SMF \\
\hline$\alpha$-Endosulfan & 3.99 & 9.52 & 13.24 & 31.69 & 0.99 & 0.89 & 0.017389 & 0.0728 \\
\hline$\alpha$-Endosulfan(non-Fungal Control) & 60.55 & 106.52 & 201.14 & 353.8561 & 0.86 & 0.8412 & 0.01144 & 0.0065 \\
\hline$\beta$-Endosulfan & 44.12 & 20.0864 & 146.56 & 66.7255 & 0.8 & 0.926797 & 0.0157 & 0.0345 \\
\hline$\beta$-Endosulfan(non-Fungal Control) & 341.35 & 70.79 & 1139 & 235.17 & 0.7 & 0.89 & 0.002059 & 0.00979 \\
\hline
\end{tabular}

metabolite was left. This accumulation and subsequent reduction showed that SMF is a better method to remediate Endosulfan sulfate.

\section{Effect of Endosulfan on Activities of Lignolytic Enzymes}

Screening of bio remedial agents for tolerance of pesticides is very important because sometimes microbes are sensitive to lethal effects of pesticide and their growth can be severely affected. Before starting the remediation experiment, using microbes as bioremedial, it is important to test their tolerance to a particular dose of selected pesticides [33]. Some fungi are more tolerant and can grow up to $400 \mathrm{mg} \mathrm{L}^{-1}$ concentrations of Endosulfan [29].

Under SMF conditions, the activity of Laccase was $6.56 \mathrm{U} \mathrm{g}^{-1} \pm 0.23$ in control 2 at day 4, while in Endosulfan-spiked flasks, the activity was slightly
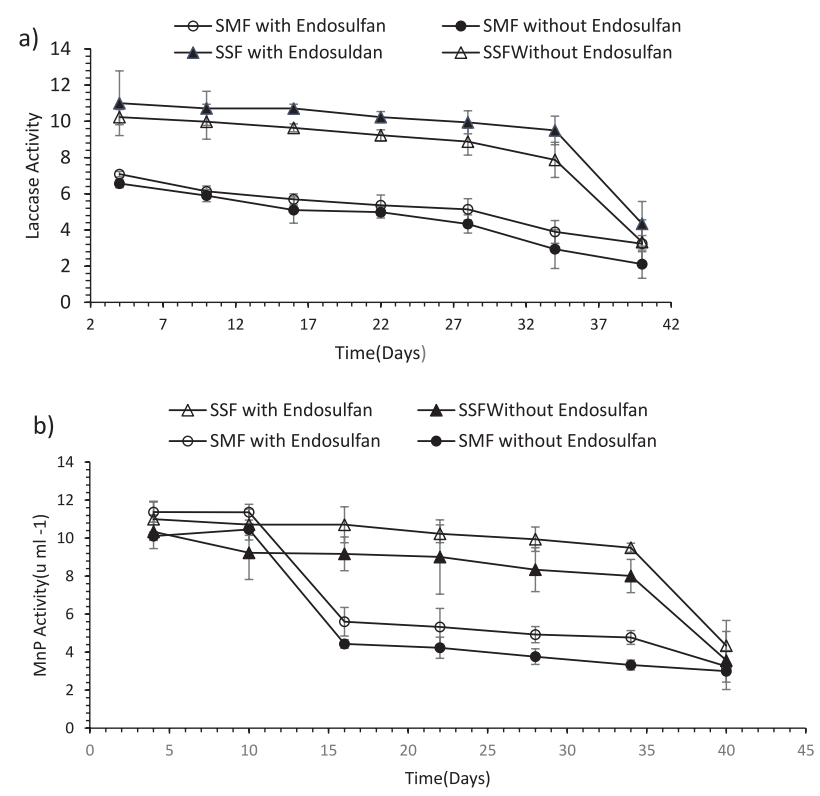

Fig. 3. Effect of Endosulfan on the activity of lignolytic enzymes during solid-state fermentation $\left(\mathrm{U} \mathrm{g}^{-1}\right)$ and submerged fermentation conditions $\left(\mathrm{Uml}^{-1}\right)$ a) laccase b) manganese peroxidase $(n=3)$. high (7.08 $\left.\mathrm{U} \mathrm{g}^{-1} \pm 0.15\right)$. The same trend was observed until the end of incubation, i.e., lower activity of Laccase in the associated controls than under Endosulfan-spiked conditions. Similarly, under SSF, Laccase higher activity was higher (11 $\mathrm{U} \mathrm{g}^{-1} \pm 0.42$ ) under Endosulfan-spiked conditions as compared to associated control $\left(10.23 \mathrm{U} \mathrm{g}^{-1}\right)$. This showed that Endosulfan pesticide had no detrimental effect on the production of Laccase activities, rather it wasslightly stimulated under both fermentation conditions. A similar pattern was also observed for another lignolytic enzyme, MnP. It is clear from Fig. 3(a, b) that activities of both the enzymes were slightly higher in Endosulfan-spiked samples than control, showing that the addition of Endosulfan has no adverse effects on their activities. This can be concluded from results that lignolytic enzymes are tolerant to selected concentrations (55 mg kg-1) of Endosulfan. P. ostreatus is considered the most tolerant fungus to many pollutants [34] and the increase in Laccase and MnP activity during the incubation under SMF and SSF conditions due to Endosulfan spiking is in accordance with the earlier observations [34] that observed the higher activity of Laccase in the presence of atrazine than its associated control. This seems unusual because generally the addition of pollutants decreases lignolytic enzyme activities.

Table 5. Pearson correlation between biodegradation of Endosulfan and lignolytic enzyme activity of Pleurotus ostreatus under solid-state fermentation and submerged fermentation (WC-814) $(\alpha=0.05)$.

\begin{tabular}{|c|c|c|c|}
\hline \multirow{2}{*}{ Conditions } & \multirow{2}{*}{ Biodegradation } & \multicolumn{2}{|c|}{$\begin{array}{c}\text { Correlation with } \\
\text { Lignolytic enzymes }\end{array}$} \\
\cline { 3 - 4 } & & Laccase & $\mathrm{MnP}$ \\
\hline \multirow{2}{*}{$\mathrm{SSF}$} & $\alpha$-Endosulfan & $0.53^{\mathrm{NS}}$ & $0.28^{\mathrm{NS}}$ \\
\cline { 2 - 4 } & $\beta$-Endosulfan & $0.39^{\mathrm{NS}}$ & $0.28^{\mathrm{NS}}$ \\
\hline \multirow{2}{*}{$\mathrm{SMF}$} & $\alpha$-Endosulfan & $0.14^{\mathrm{NS}}$ & $0.49^{\mathrm{NS}}$ \\
\cline { 2 - 4 } & $\beta$-Endosulfan & $-0.25^{\mathrm{NS}}$ & $0.1^{\mathrm{NS}}$ \\
\hline
\end{tabular}

NS $=$ Not Significant 
Correlation between Lignolytic Enzymes Activities and Reduction in Endosulfan

The majority of Pleurotus strains have an incredible capability to secrete laccase and MnP under SSF conditions, whereas under SMF conditions they secrete better hydrolytic enzymes [35]. Laccase appeared to be a major extracellular lignolytic enzyme produced by P. ostreatus in the past [36], with negligible detection of other lignin peroxidases [12]. Bioremediation of OCPs and other pollutants using WRF cultures was generally correlated with lignolytic enzyme activities in the past [17, 37, 38], while some studies have stated their non-involvement in the bioremediation process [7, 22]. However, only a limited number of researchers have studied the relationship between the extracellular lignolytic enzyme activities and reduction rates of OCPs during fermentation. During this study, a Pearson correlation between reduction (\%) of Endosulfan isomers and activities of laccase and $\mathrm{MnP}$ was calculated periodically. Results clearly demonstrated that there was no significant correlation between the activities of these enzymes and the rate of reduction of Endosulfan (Table 5). These results are contradictory to a few earlier findings and support the non-involvement of extracellular peroxidases in the metabolism of Endosulfan [27]. In a similar study using WRF (Trametes versicolor), DDT degradation had no correlation with the activity of laccase and MnP. However, LiP played some role in bioremediation [39]. Since in this case mineralization of Endosulfan was observed despite the absence of lignin peroxidase (LiP) and hence, the possibly significant role of LiP in the remediation process could be ruled out.

\section{Conclusions}

The growth conditions of any Pleurotus species significantly affect lignolytic enzyme production. During this study, Pleurotus ostreatus was grown under two different conditions: SSF and SMF. Activities of lignolytic enzymes, Laccase and Manganese peroxidase were monitored periodically during the incubation. Simultaneously, Endosulfan mineralization rate was also measured. Despite the low growth of mycelium under both fermentation conditions, degradation of Endosulfan was higher in the initial stage and subsequently declined gradually. Complete mineralization of $\alpha$-Endosulfan was achieved in 16 days under SSF conditions, while under SMF conditions, it took 10 days. Although complete degradation of $\beta$-Endosulfan took a long time under both fermentation conditions, SMF proved efficient in biodegradation of this $\beta$-isomer. Endosulfan sulfate continued to accumulate and a total of $73.69 \mathrm{mg} \mathrm{kg}^{-1}$ was observed at the termination of the incubation experiment. However, under SMF the trend was different and after accumulation of $28.28 \pm 2.35 \mathrm{mg} \mathrm{L}^{-1}$ until day 16 , it started declining to $8.71 \mathrm{mg} \mathrm{L}^{-1}$ until the end of incubation. Activity of both the enzymes, Laccase and MnP, was higher under SSF than SMF. There was no significant correlation between degradation of both the isomers and enzyme activity.

\section{Acknowledgements}

This work was supported by the International Research Support Initiative program, Higher Education Commission Islamabad, Pakistan.

\section{Conflict of Interest}

The authors declare no conflict of interest.

\section{References}

1. WAN M.T., JEN-NI K., CRAIG B., GRANT S., GRAHAM V. A., JOHN P. Toxicity of $\alpha$-, $\beta$-, $(\alpha+\beta)$-Endosulfan and their formulated and degradation products to Daphnia magna, Hyalella azteca, Oncophynchus mykiss, Oncophynchus kisutch, and biological implications in streams. Environment Toxicol. 24 (5), 1146, 2009.

2. FARRUKH S. Chronic Effects of Endosulfan on Acetylcholinesterase and Cellulase Enzyme Activity of Earthworm Eisenia Foetida. MOJ Toxicol. 3 (3), 00055, 2017.

3. ELIANA F.G.C.D., CLAUDIO A.S., OSCARLINA L.S.W., RICARDO D.V., ANTONIO B.V., ALICIO A.P. Environmental Behavior of Chlorpyrifos and Endosulfan in a Tropical Soil in Central Brazil. J Agric Food Chem. 64 (20), 3942, 2016.

4. UNECE. Risk Management Evaluation Endosulfan, Prepared by BiPRO GmbH, Germany, 2010.

5. GILLESPIE L.M.M., JIM C.P. Bioremediation, an environmental remediation technology for the bio economy. Trends biotechnol. 31 (6) 329, 2013.

6. HATAKKA A., HAMMEL K.E. Fungal Biodegradation of lignocelluloses.In: Hofrichter M. (eds) Industrial Application. The Mycota (A comprehensive Treatise on Fungi as Experimental Systems for Basic and Applied Research), 10. Springer, Berlin, Heidelberg, 2011.

7. ULČNIK A.C., KRALJ I., POHLEVEN F. Degradation of lindane and endosulfan by fungi, fungal and bacterial laccases. World J Microbiol Biotechnol. 29 (12), 2239,. 2013.

8. SILAMBARASAN S., JAYANTHI A. Mycoremediation of endosulfan and its metabolites in aqueous medium and soil by Botryosphaeria laricina JAS6 and Aspergillus tamarii JAS9. PloS one. 8 (10), 77170, 2013.

9. DESHMUKH R., ANSHUMAN A.K., HEMANT J.P. Diverse metabolic capacities of fungi for bioremediation. Indian j microbiol. 56 (3), 247, 2016.

10. ELISASHVILI V., MICHEL P., EVA K., MIKHEIL A., GIORGI K. Use of Pleurotus dryinus for lignocellulolytic enzymes production in submerged fermentation of mandarin peels and tree leaves. Enzyme Microbial Technol. 38 (7), 998, 2006. 
11. ERGUN S.O., RAZIYE O.U. Production of ligninolytic enzymes by solid state fermentation using Pleurotus ostreatus. Annals Agrar Sci. 15 (2), 273, 2017.

12. DRITSA, V., FOTIS R. The ligninolytic and biodegradation potential on lindane of Pleurotus ostreatus spp. J. Mining World Express. 2 (1), 2013.

13. VELIOĞLU, Z., RAZIYE Ö. Ü. Biosurfactant production by Pleurotus ostreatus in submerged and solid-state fermentation systems. Turkish J Biol. 39 (1), 160, 2015.

14. PAPASPYRIDI, L., NEKTARIOS A., EVANGELOS T., PAUL C., ALEXANDROS-LEANDROS S., NIKOLAS F. Submerged fermentation of the edible mushroom Pleurotus ostreatus in a batch stirred tank bioreactor as a promising alternative for the effective production of bioactive metabolites. Molecules. 17 (3), 2714, 2012.

15. CHANG B., YI-MING C. Biodegradation of toxic chemicals by Pleurotus eryngii in submerged fermentation and solid-state fermentation. J Microbiol Immunol Infect. 49 (2), 175, 2016.

16. NOVOTNY CENEK, KATERINA SVOBODOVA, PAVLA ERBANOVA, TOMAS CAJTHAMLA, APARNA KASINATHA, ELKE LANGB, VACLAV SASEKA Ligninolytic fungi in bioremediation: extracellular enzyme production and degradation rate. Soil Biol Biochem. 36, 1545, 2004

17. KARIGAR CHANDRAKANT S., SHWETHA S. RAO Role of microbial enzymes in the bioremediation of pollutants: a review. Enzyme res. 2011.

18. NASIM GHAZALA, SHAHID HAMEED MALIK, RUKHSANA BAJWA M. AFZAL, SALMAN WAJID MIAN Effect of Three Different Culture Media on Mycelial Growth of Oyster and Chinese Mushrooms. Journal of Biological Sciences, 1, 1130, 2001.

19. MEJÍA S.J., EDGARDO A. Heat treatment of wheat straw by immersion in hot water decreases mushroom yield in Pleurotus ostreatus. Revista iberoamericana de micologia. 30 (2), 125, 2013.

20. WITTAYANAN W., CHAIMONGKOL T., JONGMEVASNA W. Multiresidue method for determination of 20 organochlorine pesticide residues in fruits and vegetables using modified QuEChERS and GC-ECD/GCMSD. Int Food Res J. 24 (6), 2340, 2017.

21. SANCO. Method validation and quality control procedures for pesticide residues analysis in food and feed. European Commission, Directorate General Health and Consumer Protection, SANTE/11813/2017 (Implemented by 01.01.2018), 2017.

22. PURNOMO A.S., TOSHIO M., ICHIRO K., TAKAFUMI N., RYUICHIRO K. Application of mushroom waste medium from Pleurotus ostreatus for bioremediation of DDT-contaminated soil. Int Biodeterior Biodegradation. 64 (5), 397, 2010.

23. MÁRQUEZ-ARAQUE A.T., GERMÁN D.M.M, SERGIO S.G.M., SILVIA E.B.D, OCTAVIO L.C. Actividad fibrolítica de enzimas producidas por Trametes sp. EUM1, Pleurotus ostreatus IE8 y Aspergillus niger AD96 4 en fermentación sólida. Interciencia. 32 (11), 780, 2007.

24. SLANA M., MARIJA S. Enrofloxacin degradation in broiler chicken manure under various laboratory conditions. Environ Sci Pollution Res. 23 (5), 4422, 2016.
25. YANG C., CHUN-CHIN W., CHIH-HUNG C. Di-n-butyl phthalate removal by strain Deinococcus sp. R5 in batch reactors. Int Biodeterior Biodegradation. 95, 55, 2014.

26. BELLETTINI M.B., FERNANDA A.F., HELAYNE A.M., GERSON L.T., SUELEN Á., POLYANNA S H., AGENOR M.J., ROSEMARY H.R. Factors affecting mushroom Pleurotus spp. Saudi J Biol Sci. 2016.

27. CHANDRA R., PANKAJ C. Properties of bacterial laccases and their application in bioremediation of industrial wastes. Environ Sci Process Impacts, 17 (2), 326, 2015

28. NEGRO C.L., SENKMAN L.E., VIERLING J., REPETTI M.R., GARCÍA S.R., COLLINS P. Bioaccumulation in freshwater crabs. Endosulfan accumulation in different tissues of Zilchiopsis collastinensis P. (Decapoda: Trichodactylidae). Bulletan of Environment Contamination and Toxicology. 89 (5), 1000, 2012.

29. BHALERAO T.S., PRAVIN R.P. Biodegradation of organochlorine pesticide, endosulfan, by a fungal soil isolate, Aspergillus niger. Int Biodeterior Biodegradation. 59 (4), 315, 2007.

30. HERNANDEZ-RODRIGUEZ D., SÁNCHEZ J.E., NIETO M.G., MÁRQUEZ-ROCHA F.J. Degradation of endosulfan during substrate preparation and cultivation of Pleurotus pulmonarius. World J Microbiol Biotechnol, 22 (7), 753, 2006.

31. KAMEI I., KAZUHIRO T., RYUICHIRO K. Degradation of endosulfan and endosulfan sulfate by white-rot fungus Trametes hirsuta. J. wood sci, 57 (4), 317, 2011.

32. OZDAL MURAT, OZLEM GUR OZDAL, OMER FARUK ALGUR, ESABI BASARAN KURBANOGLU Biodegradation of $\alpha$-endosulfan via hydrolysis pathway by Stenotrophomonas maltophilia OG2. Biotech, 7 (2), 113, 2017.

33. DZIONEK A., DANUTA W., URSZULA G. Natural carriers in bioremediation: A review. Electronic J Biotechnol, 19 (5), 28, 2016.

34. CUPUL W.C., GABRIELA H.A., REFUGIO R.V., DULCE S., RIGOBERTO G.H., ENRIQUE A.G. Response of ligninolytic macrofungi to the herbicide atrazine: doseresponse bioassays. Revista Argentina de microbiologia. 46 (4), 348, 2014.

35. MUNOZ C., GUILLEN F., MARTINEZ A.T., MARTINEZ M.J. Induction and characterization of laccase in the ligninolytic fungus Pleurotus eryngii. Current microbiol. 34 (1), 1, 1997.

36. KUNJADIA P.D., GAURAV V.S., ANJU P. KUNJADIA, PRATAP N. MUKHOPADHYAY, GAURAV S. DAVE Role of ligninolytic enzymes of white rot fungi (Pleurotus spp.) grown with azo dyes. Spri Plus. 5 (1), 1487, 2016.

37. HASSAN E., ALIKHANI H. Role of Various Enzymes of Microbes in Bioremediation. 32, 2017.

38. BANSAL N., SHAMSHER S.K. Peroxidase(s) in Environment Protection. The Scientific World J. 2013.

39. SARI, AJENG ARUM, SANRO TACHIBANA Correlation of ligninolytic enzymes from the newlyfound species Trametes versicolor U97 with RBBR decolorization and DDT degradation. Water Air Soil Pollution. 223 (9), 5781, 2012. 